\title{
PENGARUH PRODUK, HARGA, TEMPAT, PROMOSI DAN KEBUTUHAN \\ MENCARI KERAGAMAN TERHADAP PERPINDAHAN \\ MEREK SAFE CARE KE MEREK LAIN
}

\author{
Putri Amalia \\ Handono Ishardyatmo \\ Henky Lesmana \\ Program Magister Ilmu Kefarmasian \\ Universitas Pancasila
}

\begin{abstract}
The presence of competitors and the number of brands that increase in the category of refreshing oil aromatherapy makes the competition increasingly tight and provides opportunities for customers to be able to make switching of brand in accordance with the wishes and expectation. This study aims to determine the effect of products, prices, places, promotions and variety seeking partially and simultaneously on brand switching of Safe Care to other brands in DKI Jakarta. Data was conducted by survey with questionnaire as an instrument, while the variables in the research were valued using Likert Scale. The samples were taken with a non-probability sampling design with purposive sampling. The number of samples used is 200 respondents. The SEM (Structural Equation Modelling) method was used as a data analysis technique. The result of this research shows that the product have significant effect on the brand switching with $t$-value 2.00, price have significant effect on the brand switching with $t$-value 2.79, place have significant effect on the brand switching with $t$ value 2.33, promotion have significant effect on the brand switching with t-value 2.05, and the variety seeking have significant effect on the brand switching with t-value 5.90. On the SEM model, product, price, place, promotion and variety seeking simultaneously have significant effect on brand switching indicates a statistical value that meets the Goodness of Fit criteria. Based on the result of the research, the conclusion that can be taken is partially and simultaneously the variable of product, price, place, promotion and variety seeking have positive and significant effect on the brand switching of Safe care to other brands in DKI Jakarta.
\end{abstract}

Keywords: product, price, place, promotiom, variety seeking, brand switching

Abstrak: Adanya pesaing dan meningkatnya jumlah merek dalam kategori minyak angin
aromaterapi membuat persaingan semakin ketat dan memberikan peluang bagi konsumen untuk
dapat melakukan perpindahan merek sesuai dengan keinginan dan harapannya. Penelitian ini
bertujuan untuk mengetahui pengaruh produk, harga, tempat, promosi dan kebutuhan mencari
keragaman secara parsial dan simultan terhadap perpindahan merek minyak angin aromaterapi Safe
Care ke merek lain di DKI Jakarta. Alat ukur yang digunakan berupa kuesioner dengan pengukuran
skala likert. Teknik pengambilan sampel yang digunakan adalah non probability dengan purposive
sampling. Jumlah sampel yang digunakan sebanyak 200 responden. Teknik analisis data yang
digunakan adalah dengan menggunakan metode analisis Structural Equation Modelling (SEM).
Hasil dari penelitian menunjukkan secara parsial variabel produk memiliki nilai t-value (2,00)
sehingga produk berpengaruh signifikan terhadap perpindahan merek, variabel harga memiliki nilai
t-value (2,79) sehingga harga berpengaruh signifikan terhadap perpindahan merek, variabel tempat
memiliki nilai t-value (2,33) sehingga tempat berpengaruh signifikan terhadap perpindahan merek,
variabel promosi memiliki nilai t-value (2,05) sehingga promosi berpengaruh signifikan terhadap
perpindahan merek dan variabel kebutuhan mencari keragaman memiliki nilai t-value (5,90)
sehingga kebutuhan mencari keragaman berpengaruh signifikan terhadap perpindahan merek.
Secara bersama-sama, pada model SEM antara pengaruh produk, harga, tempat, promosi dan
kebutuhan mencari keragaman terhadap perpindahan merek menunjukkan nilai statistik yang
memenuhi kriteria Goodness of Fit. Berdasarkan hasil penelitian, kesimpulan yang dapat diambil
yaitu variabel produk, harga, tempat, promosi dan kebutuhan mencari keragaman secara parsial dan
simultan berpengaruh terhadap perpindahan merek Safe Care ke merek lain di DKI Jakarta.

Kata kunci: produk, harga, tempat, promosi, kebutuhan mencari keragamnan, perpindahan merek 


\section{Pendahuluan}

Tingginya persentase penduduk yang mengobati sendiri menjadi peluang bagi industri farmasi untuk menyediakan produk-produk OTC (Over the Counter) atau produk yang dapat dibeli tanpa resep dokter. Masyarakat Indonesia telah lama mengenal dan menggunakan produk minyak angin untuk swamedikasi. Aroma dan kehangatannya dipercaya dapat meredakan berbagai penyakit ringan. Namun, bau menyengat dan citra sebagai produk orang tua membuat kategori produk minyak angin seperti jalan di tempat. ${ }^{1}$ Pada 2006, PT. Surabaya Indah Permai (SIP) memproduksi minyak angin aromaterapi roll on yang pertama di Indonesia yang diberi merek Safe Care. Safe Care merupakan pioneer minyak angin aromaterapi roll on, dengan inovasinya penggunaan minyak angin menjadi lebih praktis, efisien dan higienis. ${ }^{2}$ Sebagai inovasi yang pertama di Indonesia, Safe Care menerima Top Brand Award pada 2012 di kategori"Minyak angin aromatherapy". Top brand adalah penghargaan yang diberikan kepada merek-merek terbaik pilihan konsumen yang memperoleh Top Brand Index (TBI) minimum sebesar $10 \%$ dan menurut hasil survei berada dalam posisi top three. ${ }^{3}$

Tabel 1.1

Top Brand Index

\begin{tabular}{|ll|ll|l|l} 
Merek & TBI 2012 & TBI 2013 & TBI 2014 & TBI 2015 & TBI 2016 \\
\hline Fresh Care & $38,7 \%$ & $84,9 \%$ & $85,4 \%$ & $82,0 \%$ & $77,2 \%$ \\
\hline Safe Care & $31,1 \%$ & $9,6 \%$ & $6,0 \%$ & $7,2 \%$ & $7,7 \%$ \\
\hline V-Fresh & - & - & $0,9 \%$ & $2,7 \%$ & $2,8 \%$ \\
\hline Aromatic & - & - & - & - & $0,6 \%$ \\
Health Care & - & - & $0,8 \%$ & - & $0,3 \%$
\end{tabular}

Top Brand Index diukur menggunakan 3 parameter, yaitu top of mind share, top of market share dan top of commitment share. Ketiga parameter ini mampu memberikan gambaran mengenai kondisi merek di pasar. ${ }^{3}$ Hasil survei pada tabel menunjukkan merek Safe Care mengalami penurunan angka TBI yang sangat signifikan di tahun 2013. Pada tahun-tahun berikutnya, angka TBI Safe Care fluktuatif tetapi tidak sampai mencapai angka 10\% yang artinya tidak memperoleh lagi Top Brand. Menurut Kahn (2011) market share berkaitan dengan perpindahan merek. Perpindahan merek dapat juga digunakan untuk memperkirakan market share dari waktu ke waktu. Market share menggambarkan kinerja merek produk relatif terhadap merek pesaingnya. ${ }^{4}$ Data TOP Brand Index dari 2013 sampai 2016 mengindikasikan, merek Safe Care tidak lagi melekat kuat di benak konsumen dan adanya perpindahan merek ke merek pesaing.

\section{Landasan teori}

Menurut Assael (2001), perpindahan merek adalah suatu proses dimana konsumen memutuskan untuk membeli suatu produk dengan merek berbeda dari sebelumnya. ${ }^{5}$ Menurut Kotler dan Armstrong (2008) kehilangan seorang pelanggan bagi sebuah perusahaan berarti kehilangan lebih dari satu penjualan. Ini berarti kehilangan seluruh aliran pembelian yang akan dilakukan seseorang sepanjang umur hidupnya menjadi pelanggan. Dengan melihat pelanggan yang beralih dari mereknya, perusahaan dapat belajar tentang kelemahan pemasarannya dan berusaha memperbaikinya. ${ }^{6}$ Menurut Kotler dan Keller (2009), produk adalah segala sesuatu yang dapat ditawarkan pasar untuk memuaskan suatu keinginan atau kebutuhan. ${ }^{7}$ Konsumen melihat produk sebagai kumpulan manfaat kompleks yang memuaskan kebutuhan mereka. Manfaat yang akan ditawarkan produk dikomunikasikan dan dihantarkan oleh atribut produk seperti kualitas, fitur, serta gaya, desain dan sebagainya.Harga adalah jumlah uang yang harus dibayarkan pelanggan untuk memperoleh produk. Pada penelitian yang dilakukan Roos (1999), faktor pendorong yang menjadi alasan konsumen melakukan perpindahan merek yang lebih sering diungkapkan oleh konsumen salah satunya adalah harga. Pasar dimana produk harga rendah mempunyai market share besar menunjukkan bahwa pasar tersebut sensitif terhadap harga. ${ }^{9}$ Menurut Albach (2000), perbedaan harga yang lebih tinggi antarmerek merupakan penyebab perpindahan merek. ${ }^{10}$ 
Tempat menurut Kotler dan Armstrong (2008), meliputi kegiatan perusahaan yang membuat produk tersedia bagi pelanggan sasaran. Menurut Simamora (2003), tempat bagi produsen adalah bagaimana mendekatkan produk kepada konsumen agar tersedia dalam tempat dan jumlah yang tepat. Sementara itu, bagi konsumen, tempat adalah kenyamanan atau kemudahan untuk memperoleh produk. ${ }^{11}$ Pada penelitian yang dilakukan Roos (1999), faktor pendorong yang menjadi alasan konsumen melakukan perpindahan merek yang lebih sering diungkapkan oleh konsumen selain harga adalah lokasi. ${ }^{8}$ Promosi merupakan aktivitas yang menyampaikan manfaat produk dan membujuk pelanggan membelinya. ${ }^{6}$ Tanggapan konsumen terhadap promosi salah satunya adalah perpindahan merek. Konsumen akan beralih ke merek yang ditawarkan dengan harga promosi terendah. Perpindahan merek menggambarkan keputusan pelanggan untuk membeli berbagai merek berbeda dari merek yang tidak tersedia promosi. ${ }^{12}$

Konsumen melakukan perilaku pembelian mencari keragaman (variety-seeking buying behavior) dalam situasi yang mempunyai karakter keterlibatan konsumen rendah tetapi anggapan perbedaan merek yang signifikan. Dalam kasus semacam itu, konsumen sering melakukan banyak perpindahan merek. Perpindahan merek terjadi untuk mencari keragaman dan bukan karena ketidakpuasan. ${ }^{6}$ Salah satu penjelasan tentang mencari keragaman adalah bahwa konsumen mencoba untuk mengurangi kejenuhan dengan membeli merek baru. ${ }^{13}$ Menurut Peter dan Olson (2014), pencarian selingan merupakan komitmen kognitif untuk membeli merek yang berbeda-beda dikarenakan faktor seperti stimulasi yang terlibat dalam menjajal merek yang berbeda, rasa ingin tahu, kebaruan, atau mengatasi kebosanan terhadap barang lama yang itu-itu saja.

Banyak faktor yang dapat mempengaruhi perpindahan merek antara lain yang dipaparkan di atas meliputi produk, harga, tempat, promosi dan kebutuhan mencari keragaman. Menurut penelitian yang dilakukan Ariesta, Farizka (2012), ditemukan bahwa variabel independen (kebutuhan mencari variasi, harga dan promosi) berpengaruh secara positif dan signifikan terhadap variabel dependen (keputusan perpindahan merek) dalam studi kasus pada pelanggan SPBU Pertamina. ${ }^{14}$ Pada penelitian lainnya yang dilakukan Wibowo, Kurnaen dan Kresnamurti (2014), atribut produk dan variety seeking berpengaruh signifikan terhadap keputusan perpindahan merek handphone Nokia ke smartphone Samsung.

\section{Metodologi Penelitian}

Penelitian yang dilakukan merupakan penelitian eksplanatif dengan melakukan survei kepada konsumen yang melakukan perpindahan merek minyak angin aromaterapi dari merek Safe Care ke merek lainnya di DKI Jakarta. Alat ukur yang digunakan berupa kuesioner. Kuesioner yang akan disebarkan merupakan pernyataan yang berkaitan dengan produk, harga, tempat, promosi dan kebutuhan mencari keragaman serta perpindahan merek. Responden diberikan kesempatan untuk memilih satu diantara berbagai alternatif jawaban berjenjang yang disediakan. Setiap pernyataan dalam penelitian ini akan dinilai menggunakan skala 1 - 10 yang menjadi tingkat persetujuan responden. Penelitian korelasional dilakukan untuk mengetahui pengaruh produk, harga, tempat, promosi dan kebutuhan mencari keragaman terhadap perpindahan merek Safe Care ke merek lain di DKI Jakarta. Responden merupakan pengguna minyak angin aromaterapi yang sebelumnya menggunakan merek Safe Care kemudian berpindah ke merek lainnya. Penelitian ini dilaksanakan di DKI Jakarta.

\subsection{Populasi dan Sampel}

Populasi yang akan diteliti dalam penelitian adalah konsumen yang melakukan perpindahan merek dari merek Safe Care ke merek lain di DKI Jakarta. Dalam penelitian ini, peneliti melakukan penelitian terhadap 200 responden. Penarikan sampel dilakukan dengan menggunakan teknik penarikan sampel nonprobabilita. Teknik yang digunakan adalah teknik purposive sampling. Purposive sampling adalah teknik penentuan sampel dengan pertimbangan tertentu, proses 
pengambilan sampel dengan menentukan terlebih dahulu jumlah sampel yang akan diambil, kemudian pemilihan sampel dilakukan dengan berdasarkan tujuan-tujuan tertentu dengan tidak menyimpang dari ciri-ciri sampel yang ditetapkan. ${ }^{16}$

\subsection{Pelaksanaan Survei}

Penelitian dilaksanakan pada 5 kota/kabupaten administratif di DKI Jakarta antara lain Jakarta Pusat, Jakarta Barat, Jakarta Selatan, Jakarta Timur dan Jakarta Utara dengan pembagian jumlah responden secara proporsional, dengan syarat sampel penelitian (kriteria inklusi) yaitu berusia 17 50 tahun, tinggal di DKI Jakarta, pernah menggunakan minyak angin aromaterapi dalam 6 bulan terakhir, saat ini atau terakhir menggunakan minyak angin aromaterapi dengan merek selain merek Safe Care dan sebelumnya pernah menggunakan merek Safe Care. Periode penyebaran kuesioner dimulai pada bulan Maret - April 2017 dengan menyebarkan kepada masyarakat jakarta. Kuesioner yang disebarkan kepada 200 responden sesuai dengan prasyarat penelitian dengan jumlah responden yang telah dihitung secara proporsional terhadap 5 kota di DKI Jakarta sehingga jumlah responden tiap kota adalah sebanyak 40 responden. Peneliti menyebarkan kuesioner pada perguruan tinggi, perumahan dan perkantoran. Kemudian data mentah dimasukkan dan diolah, sehingga dihasilkan tabel berisikan profil dan karakteristik responden. Pengujian kecocokan data, dan uji hipotesis penelitian selanjutnya akan diproses dengan menggunakan program Lisrel 8.7.

\subsection{Analisis Data}

\subsubsection{Pre-test (Validitas dan Reliabilitas)}

Tahap pelaksanaan penelitian ini diawali dengan uji validitas dan reliabilitas kuesioner untuk menentukan layak atau tidaknya kuesioner digunakan dalam penelitian ini. Uji validitas dan reliabilitas dilakukan dengan menyebarkan kuesioner kepada 30 responden yang masuk kriteria inklusi. Uji Validitas dan Reliabilitas dalam penelitian ini diukur dengan menggunakan SPSS versi 20. Uji validitas dalam penelitian ini menggunakan metode korelasi Product Moment Pearson dengan tingkat signifikansi 5\%. Menurut umar (2010) suatu butir pertanyaan dikatakan valid apabila memiliki koefisien korelasi hitung $\left(\mathrm{r}_{\text {hitung }}\right)$ lebih besar daripada koefesien korelasi tabel $\left(\mathrm{r}_{\text {tabel }}\right)$ yang ditunjukkan dengan nilai $\mathrm{p}<0,05 .{ }^{17}$ Sedangkan teknik yang digunakan untuk mengukur reliabilitas dalam penelitian ini adalah Cronbach's Alpha. ${ }^{18}$ Menurut Malhotra dalam Wulandari (2012), adapun nilai Cronbach's Alpha untuk masing-masing variabel harus lebih besar dari 0,5 agar dianggap konsisten dan dapat dilakukan uji selanjutnya. Semakin besar nilai cronbach's alpha yang dihasilkan maka indikator tersebut akan semakin reliable. ${ }^{19}$

Teknik analisis data yang akan digunakan dalam penelitian adalah dengan menggunakan metode analisis Structural Equation Model (SEM). SEM merupakan suatu teknik statistik yang mampu menganalisis variabel latent, variabel indikator dan kesalahan pengukuran secara langsung. Variabel latent merupakan construct atau konsep abstrak yang menjadi perhatian yang hanya dapat diamati secara tidak langsung melalui efeknya pada variabel-variabel teramati. Variabel teramati adalah variabel yang dapat diamati atau diukur secara empiris. Variabel teramati yang merupakan efek atau ukuran dari variabel latent seringkali disebut variabel indikator. SEM mampu menganalisis hubungan antara variabel latent dengan variabel indikatornya, hubungan antara variabel latent yang satu dengan variabel latent yang lain, juga mengetahui besarnya kesalahan pengukuran. SEM termasuk keluarga multivariate statistics dependensi yang memungkinkan dilakukannya analisis satu atau lebih variabel independen dengan satu atau lebih variabel dependen. Ada beberapa program komputer yang dapat digunakan untuk menganalisis SEM, salah satunya adalah LISREL, dan dalam penelitian menggunakan software LISREL 8.7. ${ }^{18}$

Langkah-langkah yang dilakukan untuk membuat model SEM yaitu:

1. Pengembangan model berbasis teori 
Kegiatan dalam langkah pertama ini adalah mengembangkan model hipotetik, artinya mengembangkan suatu model berdasarkan kajian-kajian teoritik. Selanjutnya model ini diuji berdasarkan atas data empirik melalui SEM. Dalam mengembangkan pemodelan, peneliti harus memiliki wawasan dan landasan teori yang luas yang berkaitan dengan permasalahan yang diteliti. Hasil kajian atau eksplorasi terhadap teori-teori yang relevan akan membentuk model hipotetik untuk kemudian diverifikasi berdasarkan data empirik dengan menggunakan SEM.

2. Mengkonstruksi diagram jalur untuk hubungan kausal

Diagram jalur sangat berguna untuk melihat hubungan kausal antara variabel eksogen dan variabel endogen. Hubungan kausal antar variabel ini divisualisasikan dalam bentuk gambar sehingga mudah dan jelas untuk dipahami secara lebih menarik. Menurut Sitinjak dan Sugiarto (2006) Variabel eksogen adalah variabel yang berasal dari luar model dan merupakan input bagi model. Variabel endogen berasal dari dalam model dan merupakan output dari model. Dalam model, simbol anak panah () dipergunakan untuk menunjukkan adanya hubungan kausal (ekor anak panah untuk variabel penyebab dan kepala anak panah untuk variabel akibat).

3. Mengkonversi diagram jalur kedalam model struktural dan model pengukuran

4. Memilih matrik input dan estimasi model

Dalam SEM, matrik inputnya dapat berupa matrik korelasi atau matrik varians-kovarians. Matrik korelasi digunakan untuk tujuan memperoleh kejelasan tentang pola hubungan kausal antar variabel laten. Dengan matrik ini, peneliti dapat melihat dua hal, yaitu: pertama, jalur-jalur mana yang memilik efek kausal yang lebih dominan dibandingkan dengan jalur-jalur yang lain, dan kedua, variabel eksogen yang mana yang efeknya lebih besar terhadap variabel endogen dibandingan dengan variabel lainnya. Matrik varians-kovarians digunakan untuk pengujian model yang telah dilandasi berbagai kajian teori. Analisis yang dilakukan tidak untuk melihat besar kecilnya efek kausal pada jalur-jalur yang ada dalam model. Hasil analisis yang diperoleh dapat digunakan untuk eksplanasi fenomena yang diteliti atau untuk keperluan prediksi.

5. Menilai identifikasi model struktural

Beberapa gejala yang sering muncul akibat adanya ketidaktepatan identifikasi antara lain terdapat kesalahan standar yang terlalu besar, matriks informasi yang disajikan tidak sesuai harapan, matriks yang diperoleh tidak definitif positif, terdapat kesalahan varians yang negatif dan terdapat korelasi yang tinggi antar koefisien hasil dugaan $(>0.9)$.

6. Evaluasi kecocokan model berdasarkan kriteria Goodness-of-fit

Pengujian model struktural dilakukan untuk mengetahui sejauhmana model hubungan antar variabel yang disusun secara teoritis didukung oleh kenyataan yang ada pada data empiri. Uji kesesuaian antara model teoritis dan data empiri dapat dilihat pada tingkat (goodness of fit statistics).

7. Intepretasi dan modifikasi model

Langkah terakhir dari SEM adalah melakukan interpretasi bilamana model yang dihasilkan sudah cukup baik. Interpretasi dilakukan terhadap model struktural yang menggunakan matrik kovarians dan interpretasi terhadap analisis jalur yang menggunakan matrik korelasi. Khusus untuk interpretasi pada analisis jalur yang dilihat antara lain: efek langsung, efek tak langsung dan efek total.

\subsubsection{Uji Hipotesis}

Pengujian hipotesis dilakukan terhadap enam hipotesis yang telah diajukan dan diolah menggunakan program Lisrel 8.7. Pengujian dilakukan dengan menggunakan kriteria Goodness of Fit (GOF), dan nilai t-value, jika nilai yang diperoleh $\geq 1,96$ maka hipotesis diterima. 
Tabel 4.1

Hasil Uji Validitas

\begin{tabular}{|c|c|c|c|c|}
\hline Variabel & Indikator & r-hitung & r-tabel & Kesimpulan \\
\hline \multirow[t]{8}{*}{ Produk } & $\mathrm{AP} 1$ & 0,375 & 0,361 & Valid \\
\hline & AP2 & 0,459 & 0,361 & Valid \\
\hline & AP3 & 0,584 & 0,361 & Valid \\
\hline & AP4 & 0,601 & 0,361 & Valid \\
\hline & AP5 & 0,666 & 0,361 & Valid \\
\hline & AP6 & 0,764 & 0,361 & Valid \\
\hline & AP7 & 0,421 & 0,361 & Valid \\
\hline & AP8 & 0,609 & 0,361 & Valid \\
\hline \multirow[t]{5}{*}{ Harga } & HR1 & 0,477 & 0,361 & Valid \\
\hline & HR2 & 0,759 & 0,361 & Valid \\
\hline & HR3 & 0,828 & 0,361 & Valid \\
\hline & HR4 & 0,723 & 0,361 & Valid \\
\hline & HR5 & 0,879 & 0,361 & Valid \\
\hline \multirow[t]{5}{*}{ Tempat } & TP1 & 0,897 & 0,361 & Valid \\
\hline & $\mathrm{TP} 2$ & 0,881 & 0,361 & Valid \\
\hline & TP3 & 0,809 & 0,361 & Valid \\
\hline & TP4 & 0,907 & 0,361 & Valid \\
\hline & TP5 & 0,792 & 0,361 & Valid \\
\hline \multirow[t]{8}{*}{ Promosi } & PR1 & 0,443 & 0,361 & Valid \\
\hline & PR2 & 0,663 & 0,361 & Valid \\
\hline & PR3 & 0,626 & 0,361 & Valid \\
\hline & PR4 & 0,795 & 0,361 & Valid \\
\hline & PR5 & 0,592 & 0,361 & Valid \\
\hline & PR6 & 0,441 & 0,361 & Valid \\
\hline & PR7 & 0,451 & 0,361 & Valid \\
\hline & PR8 & 0,505 & 0,361 & Valid \\
\hline \multirow{6}{*}{$\begin{array}{l}\text { Kebutuhan } \\
\text { mencari } \\
\text { keragaman }\end{array}$} & KMK1 & 0,571 & 0,361 & Valid \\
\hline & KMK2 & 0,777 & 0,361 & Valid \\
\hline & KMK3 & 0,797 & 0,361 & Valid \\
\hline & KMK4 & 0,736 & 0,361 & Valid \\
\hline & KMK5 & 0,747 & 0,361 & Valid \\
\hline & KMK6 & 0,840 & 0,361 & Valid \\
\hline \multirow{7}{*}{$\begin{array}{l}\text { Perpindahan } \\
\text { merek }\end{array}$} & PM1 & 0,715 & 0,361 & Valid \\
\hline & PM2 & 0,630 & 0,361 & Valid \\
\hline & PM3 & 0,759 & 0,361 & Valid \\
\hline & PM4 & 0,591 & 0,361 & Valid \\
\hline & PM5 & 0,862 & 0,361 & Valid \\
\hline & PM6 & 0,425 & 0,361 & Valid \\
\hline & PM7 & 0,730 & 0,361 & Valid \\
\hline
\end{tabular}

Butir pernyataan dikatakan valid jika nilai $r$ hitung lebih besar daripada $r$ tabel pada tingkat signifikansi 0,05. Pada Tabel diatas menunjukkan bahwa seluruh indikator memperoleh nilai $\mathrm{r}$ hitung $>$ r-tabel $(0,361)$. Sehingga dapat disimpulkan bahwa seluruh indikator yang digunakan dalam penelitian ini adalah valid.

Tabel 4.2

Hasil Uji reliabilitas

\begin{tabular}{|l|cc|}
\hline \multicolumn{1}{c|}{ Variabel } & Cronbach's Alpha & Kesimpulan \\
\hline Produk & 0,742 & Reliable \\
\hline Harga & 0,783 & Reliable \\
\hline Tempat & 0,909 & Reliable \\
\hline Promosi & 0,799 & Reliable \\
\hline Kebutuhan mencari keragaman & 0,798 & Reliable \\
\hline Perpindahan merek & 0,800 & Reliable \\
\hline
\end{tabular}

Nilai Cronbach's Alpha akan menunjukkan bahwa suatu instrumen dapat dikatakan handal (reliable) bila memiliki koefisien reliabilitas atau alpha sebesar 0,6 atau lebih. Dari hasil uji 
reliabilitas pretest di atas diperoleh nilai Cronbach's Alpha masing-masing variabel lebih besar dari 0,6 sehingga dapat disimpulkan bahwa butir - butir instrumen penelitian tersebut reliabel.

\subsubsection{Profil dan karakteristik responden}

Berikut ini adalah profil dan karakteristik dari 200 responden yang memenuhi kriteria inklusi

Tabel 4.3

Karakteristik Responden

\begin{tabular}{|c|c|c|c|}
\hline Variabel & Kategori & Frekuensi & Prosentase \\
\hline Jenis kelamin & Perempuan & 167 responden & $83,5 \%$ \\
\hline Usia & $17-25$ tahun & 103 responden & $51,5 \%$ \\
\hline Pendidikan terakhir & SMA & 83 responden & $41,5 \%$ \\
\hline Pekerjaan & Karyawan swasta & 95 responden & $47,5 \%$ \\
\hline $\begin{array}{l}\text { Pengeluaran kesehatan } \\
\text { per bulan }\end{array}$ & $<$ Rp. 100.000 & 96 responden & $48,0 \%$ \\
\hline $\begin{array}{l}\text { Tujuan penggunaan } \\
\text { produk }\end{array}$ & Masuk angin & 151 responden & - \\
\hline Tempat membeli produk & $\begin{array}{l}\text { Minimarket atau } \\
\text { supermarket }\end{array}$ & 173 responden & - \\
\hline $\begin{array}{l}\text { Range harga merek lain } \\
\text { yang terakhir dipakai }\end{array}$ & Rp. $10.000-15.000$ & 130 responden & $65 \%$ \\
\hline
\end{tabular}

\subsubsection{Pengujian Model Pengukuran}

Pengujian model pengukuran dengan menggunakan Confirmatory Factor Analysis (CFA). Dalam proses ini, menguji apakah tiap-tiap variabel manifes/indikator benar-benar mampu mengukur/mencerminkan variabel latennya. Loading factor merupakan besar korelasi antara indikator dengan konstruk latennya. Indikator dengan loading factor yang tinggi memiliki konstribusi yang lebih tinggi untuk menjelaskan konstruk latennya. Sebaliknya pada indikator dengan loading factor rendah memiliki konstribusi yang lemah untuk menjelaskan konstruk latennya. Pada sebagian besar referensi bobot faktor sebesar 0,50 atau lebih dianggap memiliki validasi yang cukup kuat untuk menjelaskan konstruk laten. Pengujian model pengukuran dilakukan pada semua variabel sebagai berikut.

Tabel 4.4

Model Pengukuran

\begin{tabular}{|c|c|c|c|c|}
\hline Variabel & Indikator & Nilai Loading & Standar Loading & Kesimpulan \\
\hline \multirow[t]{8}{*}{ Produk } & AP1 & 0,70 & 0,50 & Valid \\
\hline & AP2 & 0,75 & 0,50 & Valid \\
\hline & AP3 & 0,72 & 0,50 & Valid \\
\hline & AP4 & 0,58 & 0,50 & Valid \\
\hline & AP5 & 0,59 & 0,50 & Valid \\
\hline & AP6 & 0,79 & 0,50 & Valid \\
\hline & AP7 & 0,55 & 0,50 & Valid \\
\hline & AP8 & 0,59 & 0,50 & Valid \\
\hline \multirow[t]{5}{*}{ Harga } & HR1 & 0,97 & 0,50 & Valid \\
\hline & HR2 & 0,83 & 0,50 & Valid \\
\hline & HR3 & 0,88 & 0,50 & Valid \\
\hline & HR4 & 0,50 & 0,50 & Valid \\
\hline & HR5 & 0,79 & 0,50 & Valid \\
\hline \multirow[t]{5}{*}{ Tempat } & TP1 & 0,92 & 0,50 & Valid \\
\hline & TP2 & 0,94 & 0,50 & Valid \\
\hline & TP3 & 0,78 & 0,50 & Valid \\
\hline & TP4 & 0,79 & 0,50 & Valid \\
\hline & TP5 & 0,67 & 0,50 & Valid \\
\hline
\end{tabular}




\begin{tabular}{|c|c|c|c|c|}
\hline \multirow[t]{8}{*}{ Promosi } & PR1 & 0,77 & 0,50 & Valid \\
\hline & PR2 & 0,83 & 0,50 & Valid \\
\hline & PR3 & 0,87 & 0,50 & Valid \\
\hline & PR4 & 0,73 & 0,50 & Valid \\
\hline & PR5 & 0,51 & 0,50 & Valid \\
\hline & PR6 & 0,84 & 0,50 & Valid \\
\hline & PR7 & 0,77 & 0,50 & Valid \\
\hline & PR8 & 0,85 & 0,50 & Valid \\
\hline \multirow{6}{*}{$\begin{array}{l}\text { Kebutuhan mencari } \\
\text { keragaman }\end{array}$} & KMK1 & 0,86 & 0,50 & Valid \\
\hline & KMK2 & 0,81 & 0,50 & Valid \\
\hline & KMK3 & 0,82 & 0,50 & Valid \\
\hline & KMK4 & 0,68 & 0,50 & Valid \\
\hline & KMK5 & 0,60 & 0,50 & Valid \\
\hline & KMK6 & 0,74 & 0,50 & Valid \\
\hline \multirow[t]{7}{*}{ Perpindahan Merek } & PM1 & 0,78 & 0,50 & Valid \\
\hline & PM2 & 0,55 & 0,50 & Valid \\
\hline & PM3 & 0,74 & 0,50 & Valid \\
\hline & PM4 & 0,69 & 0,50 & Valid \\
\hline & PM5 & 0,77 & 0,50 & Valid \\
\hline & PM6 & 0,79 & 0,50 & Valid \\
\hline & PM7 & 0,65 & 0,50 & Valid \\
\hline
\end{tabular}

Berdasarkan hasil diatas dapat dilihat bahwa tiap indikator sudah memenuhi syarat, yaitu loading factor diatas 0,50 sehingga semua indikator dapat diterima dan mampu menerangkan variabel laten.

\subsection{Uji Kecocokan Keseluruhan Model}

Setelah diketahui tiap - tiap variabel manifes/indikator benar-benar mampu mengukur/mencerminkan variabel latennya, tahap selanjutnya adalah melakukan analisis kecocokan data dengan model secara keseluruhan atau disebut Goodness of Fit (GOF). Umumnya terhadap berbagai jenis fit index yang digunakan untuk mengukur derajat kesesuaian antara model yang dihipotesiskan dengan data yang disajikan. Berikut ini adalah hasil pengujian indeks kesesuaian dan cut-off valuenya untuk digunakan dalam menguji apakah sebuah model dapat diterima atau di tolak.

Tabel 4.5

Evaluasi Goodness of fit Index

\begin{tabular}{cccc} 
Goodness of Fit Index & Hasil Model & Cut-off Value & $\begin{array}{c}\text { Keteranga } \\
\mathbf{n}\end{array}$ \\
\hline $\begin{array}{c}\text { Goodness of Fit Indices } \\
\text { (GFI) }\end{array}$ & 0,96 & $\geq 0,90$ & Good Fit \\
$\begin{array}{c}\text { Root Mean Square Error } \\
\text { of Approximation } \\
\text { (RMSEA) }\end{array}$ & 0,070 & $\leq 0,08$ & Good Fit \\
$\begin{array}{c}\text { Adjusted GFI (AGFI) } \\
\text { Normed Fit Index (NFI) }\end{array}$ & 0,90 & $\geq 0,90$ & Good Fit \\
$\begin{array}{c}\text { Comparative Fit Index } \\
\text { (CFI) }\end{array}$ & 0,90 & $\geq 0,90$ & Good Fit \\
$\begin{array}{c}\text { Incremental Fit Index } \\
\text { (IFI) }\end{array}$ & 0,94 & $\geq 0,90$ & Good Fit \\
$\begin{array}{c}\text { Relative Fit Index (RFI) } \\
\text { Parsimonious Normed Fit } \\
\text { Index (NNFI) }\end{array}$ & 0,91 & $\geq 0,90$ & Good Fit \\
\hline
\end{tabular}


Berdasarkan Tabel Evaluasi Goodness of Fit Indices menunjukkan bahwa seluruh tingkat kecocokan dapat diterima, yaitu nilai GFI, AGFI, NFI, CFI, IFI, RFI dan NNFI hasil lebih besar dari nilai cut off sedangkan nilai RSMEA berada dibawah nilai cut off. Hal ini menunjukkan bahwa seluruh model adalah fit.

\subsubsection{Pengujian Hipotesis}

Setelah melakukan uji kecocokan keseluruhan model, maka tahap selanjutnya adalah menguji hipotesis penelitian pada model strukturalnya. Pengujian hipotesis dilakukan untuk mengetahui bagaimana hubungan antara variabel produk, harga, tempat, promosi dan kebutuhan mencari keragaman terhadap perpindahan merek. Untuk mengetahui suatu variabel memiliki pengaruh yang signifikan atau tidak, dapat dilihat dari nilai t-hitung. Jika nilai t-value $>1,96$ maka variabel tersebut dikatakan memiliki pengaruh signifikan. Berikut ini merupakan nilai t-value dari masing-masing variabel penelitian.

Tabel 4.6

Evaluasi Pengujian Hipotesis

\begin{tabular}{clccc} 
Hipotesis & \multicolumn{1}{c}{ Path } & t-value & Loading & Kesimpulan \\
\hline 1 & $\begin{array}{l}\text { Produk } \rightarrow \text { Perpindahan } \\
\text { merek }\end{array}$ & 2,00 & 0,14 & Berpengaruh \\
2 & $\begin{array}{l}\text { Harga } \rightarrow \text { Perpindahan } \\
\text { merek }\end{array}$ & 2,79 & 0,36 & Berpengaruh \\
\hline 3 & $\begin{array}{l}\text { Tempat } \rightarrow \text { Perpindahan } \\
\text { merek }\end{array}$ & 2,33 & 0,17 & Berpengaruh \\
\hline 5 & $\begin{array}{l}\text { Promosi } \rightarrow \text { Perpindahan } \\
\text { merek }\end{array}$ & 2,05 & 0,16 & Berpengaruh \\
\hline 6 & $\begin{array}{l}\text { Kebutuhan mencari } \\
\text { keragaman } \rightarrow\end{array}$ & 5,90 & 0,40 & Berpengaruh \\
Perpindahan merek & $\begin{array}{l}\text { Produk, harga, tempat, } \\
\text { promosi dan kebutuhan } \\
\text { mencari keragaman } \rightarrow \\
\text { Perpindahan merek }\end{array}$ & $*$ & & Berpengaruh \\
\hline
\end{tabular}

*Dilihat dari hasil evaluasi uji kecocokan model secara keseluruhan (Goodness of Fit) pada Tabel Evaluasi Goodness of Fit Indices

\section{Simpulan dan Saran}

Produk, Harga, Tempat, Promosi dan kebutuhan mencari keragaman memiliki hubungan positif dan signifikan baik secara partial maupun secara simultan atau bersama-sama terhadap perpindahan merek.

1. Secara parsial, produk memiliki hubungan positif dan signifikan berpengaruh terhadap perpindahan merek sebesar 0,14 ( $t$-value 2,00 ) yang berarti $t$-value lebih besar dari angka signifikansi pada alfa $5 \%$ yaitu 1,96 . Hasil tersebut dapat diartikan bahwa sub-variabel pada produk yang dipilih dalam penelitian ini signifikan dan sudah representatif dalam mempengaruhi perpindahan merek.

2. Secara parsial, harga memiliki hubungan positif dan signifikan berpengaruh terhadap perpindahan merek sebesar 0,36 ( $t$-value 2,79$)$ yang berarti $t$-value lebih besar dari angka signifikansi pada alfa 5\% yaitu 1,96. Hasil tersebut dapat diartikan bahwa sub-variabel pada harga yang dipilih dalam penelitian ini signifikan dan sudah representatif dalam mempengaruhi perpindahan merek.

3. Secara parsial, tempat memiliki hubungan positif dan signifikan berpengaruh terhadap perpindahan merek sebesar 0,17 ( $t$-value 2,33 ) yang berarti $t$-value lebih besar dari angka 
signifikansi pada alfa $5 \%$ yaitu 1,96 . Hasil tersebut dapat diartikan bahwa sub-variabel pada tempat yang dipilih dalam penelitian ini signifikan dan sudah representatif dalam mempengaruhi perpindahan merek.

4. Secara parsial, promosi memiliki hubungan positif dan signifikan berpengaruh terhadap perpindahan merek sebesar 0,16 (t-value 2,03) yang berarti t-value lebih besar dari angka signifikansi pada alfa $5 \%$ yaitu 1,96 . Hasil tersebut dapat diartikan bahwa sub-variabel pada promosi yang dipilih dalam penelitian ini signifikan dan sudah representatif dalam mempengaruhi perpindahan merek.

5. Secara parsial, kebutuhan mencari keragaman memiliki hubungan positif dan signifikan berpengaruh terhadap perpindahan merek sebesar 0,40 ( $t$-value 5,90$)$ yang berarti $t$-value lebih besar dari angka signifikansi pada alfa $5 \%$ yaitu 1,96 . Hasil tersebut dapat diartikan bahwa subvariabel pada kebutuhan mencari keragaman yang dipilih dalam penelitian ini, signifikan dan sudah representatif dalam mempengaruhi perpindahan merek.

6. Secara bersama-sama kelima variabel laten eksogen produk, harga, tempat, promosi dan kebutuhan mencari keragaman berpengaruh secara signifikan terhadap variabel laten endogen perpindahan merek dilihat dari analisis statistik yang telah memenuhi syarat pada uji analisis kecocokan model secara keseluruhan (Goodness of Fit).

\section{Daftar Pustaka}

Ariesta, Farizka. 2012. Pengaruh Kualitas Layanan, Kebutuhan Mencari Variasi, Harga, Karakteristik Kategori Produk, Promosi Iklan dan Kualitas Produk terhadap Keputusan Perpindahan Merek. Tesis. Jakarta: Universitas Indonesia.Prahadi, YY. Resep Fresh Care Kuasai Pasar Minyak Angin. 20 Agustus 2015. SWA Online Magazine. Diambil dari: http//www.swa.co.id/swa/trends/management/resep-fresh-care-kuasai-pasar tanggal 13 Januari 2017. http://www.safecarearomatherapy.com/

Assael, Henry. 2001. Consumer Behaviour and Marketing Action. $6^{\text {th }}$ ed. Cincianiti, Ohio: South Western College Publishing.Kahn, KB. 2011. Product Planning Essentials. $2^{\text {nd }}$ ed. NewYork: M.E.Sharpe. Inc. Hlm. 206.

Arifin, Johar. 2008. Statistik Bisnis Terapan dengan Microsoft Excel 2007. Jakarta: Gramedia. Hlm. 12-13.Kotler, P. dan Armstrong, G. 2008. Prinsip - Prinsip Pemasaran. Edisi 12. Jilid 1. Jakarta: Erlangga. Hlm. 179

Kotler, P. dan Keller, KL. 2009. Manajemen Pemasaran. Edisi 13. Jilid 1. Jakarta: Erlangga. Hlm. 258, 151-152.

Mowen, JC dan Minor, M. 2002. Perilaku Konsumen. Jakarta: Erlangga. Hlm. 11-12, 64-66Peter, JP. dan Olson, JC. 2014. Perilaku Konsumen dan Strategi Pemasaran. Edisi 9. Jakarta: Salemba Empat. Roos, Inger. 1999. Switching Processes in Customer Relationships. Journal of Service Research. Volume 2. No.1. Agustus 1999. H1m. 68-85.

Sugiyono. 2016. Statistika untuk Penelitian. Bandung: Alfabeta. Hlm. 61-67.Sampurno. 2009. Manajemen Pemasaran Farmasi. Yogyakarta: Gadjah Mada University Press. Hlm. 188$189,153-153,233-235,320$

Simamora, Balson. 2003. Memenangkan Pasar dengan Pemasaran Efektif dan Profitabel. Jakarta: Gramedia Pustaka Utama. Hlm. 36-37.

Sitinjak, Tumpal JR dan Sugiarto. 2006. Lisrel. Yogyakarta : Graha Ilmu. Hlm. 70-71.Wiehenbrauk, Daniela. 2010. Collaborative Promotions. Germany: Springer. Hlm. 20.

Umar, H. 2010. Riset Pemasaran dan Perilaku Konsumen. Jakarta: Gramedia Pustaka Utama. Wibowo, SF., Kurnaen, Teguh dan Kresnamurti, Agung. 2014. Pengaruh Atribut Produk dan Variety Seeking terhadap Keputusan Perpindahan Merek Handphone Nokia ke Smartphone Samsung. Jurnal Riset Manajemen Sains Indonesia (JRMSI). Vol 5. No.1. 2014. Hlm. 21-41.

Wulandari, Widya. 2012. Analisis Perilaku Brand Switching Konsumen Dalam Pembelian Produk Pelembab Wajah. Tesis. Jakarta: Universitas Indonesia. 